\title{
Curricular Changes in Higher Education in Mexico (2002-2012)
}

\author{
Frida Díaz-Barriga ${ }^{1, *}$ \& María Concepción Barrón ${ }^{2}$ \\ ${ }^{1}$ Faculty of Psychology, National Autonomous University of Mexico, Mexico \\ ${ }^{2}$ Institute for Research on University and Education (IISUE), National Autonomous University of Mexico, Mexico \\ *Corresponding author: Faculty of Psychology, National Autonomous University of Mexico, Avenida Universidad \\ 3004, Colonia Universidad Nacional, Delegación Coyoacán, D.F. 04510, México. Tel: 52-55-5622-2237. E-mail: \\ diazfrida@prodigy.net.mx
}

Received: May 25, 2014

Accepted: June 25, $2014 \quad$ Online Published: July 28, 2014

doi:10.5430/jct.v3n2p58

URL: http://dx.doi.org/10.5430/jct.v3n2p58

\begin{abstract}
Based on the analysis of 1241 documents published in Mexico (2002-2012) concerning curriculum studies, we find that the issue of innovation was addressed in 6 out of 10 research papers that focused on the higher education level (60.4\%). It shows an increase in empirical research, quantitative and qualitative, that accounts for the process of implementation of innovative curriculum models and recover the experiences of his actors. There is still a predominance of neoliberal discourse and a vertical approach in curricular reforms, the "top-down curriculum design", but there are also examples of active agency of actors (mostly teachers and students), ranging from acts of resistance and rejection, to proactive experiences in their academic communities based on the organization of groups of teachers or researchers who took a leading role and achieved successful experiences related to the needs of their context. The lack of a systemic change approach, and especially appropriate teacher training processes, are the main obstacle to educational change prescribed in the curricular reforms in Mexico. In higher education are two important issues: the competency based education approach and the curricular flexibility. In both terms prevails polysemy, and there are no consistent attempts to innovation through them in the sense of changing conceptions and practices in the classrooms. The competencies approach suffers a "pedagogical vacuum", and in some curricular reforms it has tried to fill in several ways, primarily the adoption of business models or neo-behaviorists conceptions transferred to universities. The flexible curriculum is not only a technical issue, because of its implications in the management and administration of universities, as well as in school practices and processes. There is evidence that the most important problems in their implementation concerns legal aspects, academic organization and operation, as well as by the lack of mentoring and academic mobility of students and teachers.
\end{abstract}

Keywords: curricular reforms; higher education; innovation of curriculum models; competencies and curriculum; curricular flexibility

\section{Introduction}

\subsection{Curriculum Studies in Mexico}

In the field of curriculum in Mexico it is impossible to find an unique or comprehensive approach that could include all and each of the subjects of study, problems or situations that pertain to such field. Depending on the way curriculum is conceived, the idea of curriculum research and its method will be determined, and so will be fixed, at the level of intervention, the conceptual and technical character of its design and evaluation. But, at the same time, although contemporary curriculum research has been originated in the United States its recontextualization worldwide in nations with distinctive histories and cultures (as Mexico) underline its localized and reconstructed character (Pinar, 2014). Following Kumar's ideas (2011) it is possible to identify three phases in the evolution of the studies about curriculum in Mexico. The first one starts in the seventies with the broad spreading of Tyler's theories about curriculum and the vision of several American authors about the technologic-behaviorist approach. The second phase takes place during the eighties and is due to the strenghtening and institutionalization of the curriculum studies in four communities who formulate theories and proposals about curriculum: critical pedagogy, constructivism, the interpretative school and the studies about professional training and practice. According to the above mentioned 
author, the third phase starts in the nineties and is characterized by the globalization processes of curriculum reforms and models, and also by the neoliberal notions of innovation and accreditation, whereas at the same time the discourse of postmodern and post-structuralist curriculum theories is gaining ground in academic settings. So, it can be said that curriculum studies in Mexico - as in many other countries- have entered a stage of internationalization and that interest in curricular reforms centered on the theme of innovation is the most prominent. In this last stage of internationalization several authors found important strains between the global, national and local spheres (García-Garduño, 2011; Pinar, 2014). Thus, we assume the existence of a tension between global trends and situated character of curriculum studies in our country.

By taking into account the evolution of curriculum studies in Mexico, we agree with García-Garduño (2011), who says that this field of research is characterized by processes of acculturation and satellization. This is because it has happened subordination and assimilation in Mexico regarding the ideology and theories on curriculum from other countries, mainly United Sates and to a lesser extent Spain, France and Great Britain. However, at the same time, there are also hybridization processes, since structures and practices that stem from diverse origins can combine in order to create new entities in a kind of crossbreeding process which is never free from contradictions and exclusions. In this area is that we place the current interest in the discourse of innovation in curriculum and teaching educational intituciones, particularly in higher education, as a response to changes in the economy and society of this millennium (Barrón, 2011). But at the same time, we must recognize that although the prevalent discourse is not unique.

From other point of view, important domains of criticism arose from Mexican scholars, with regard to the cultural and ideological hegemony of the neoliberal curriculum approaches upon Latin America and Mexico, concerning the phenomenon of scientific and technological dependence. The main discussion was about the fact that the real function of school is to perpetuate the social inequalities and injustices and to validate the hegemonic ways of knowledge and culture of the domineering groups of society. In the case of the Mexican authors of the critical theories of curriculum, we observe at least during three decades the generation of critical essays and alternative curriculum proposals, focused on discourses of emancipation and liberation. Another important discourse arises from studies in wich the main interest is to analyze the subjective and intersubjective meanings informed by the teachers, students and authorities, in this sense, they are studies that try to get to the bottom of the interpretation that people have about their own experience related to curriculum. In the case of several interpretative studies, curriculum is studied taking as analysis unit the "texts" and discourses generated by the actors, and therefore the interest is to observe how the identity construction process takes place in them (Díaz Barriga, 2014). Many of these studies show the contradictions of policies and innovative projects of education authorities in turn. Mainly, ignorance of the conditions under which educational institutions operate, prevailing methods of instruction, teachers training models and the lack of systemic changes appear recurrently (Díaz Barriga, 2010).

\subsection{Purpose if this Article}

Considering these trends and processes, in this article we will attempt to present the analysis of curriculum studies in Mexico concerning the topic of innovation during the most recent decade (2002-2012). Our purpose was to identify what is meant by innovation of curriculum and the instructional models considered. While talking about the education system as a whole, we focus on higher education, because it is where there is more research. Also, we try to identify the research results about the role of teachers and students to the curriculum reforms and the conditions that they report in their schools that facilitate or impede educational change.

\section{Method}

\subsection{Type of Research}

We conducted a state of knowledge: a study which aims to select, sort, organize and describe the scientific production in a specific area, providing an overview of it (Mardones \& Ursúa, 2003). With the intention of a systemic view, the findings were analyzed using a mixed method research -qualitative and quantitative- (Creswell \& Plano-Clark, 2010).

This study is based on the analysis carried out with the support of the Mexican Council for Educational Research (Consejo Mexicano de Investigación Educativa, COMIE) that takes into account the situation in the eighties and nineties concerning curriculum studies in our country (Díaz Barriga, Barrón, Carlos, Díaz Barriga, Torres, Spitzer \& Ysunza, 1995; Díaz Barriga \& Lugo, 2003). We can say that in relation to the previous two decades, production in the field of curriculum studies has increased significantly. In absolute numbers, in the eighties we were able to 
retrieve and analyze 235 documents, in the nineties were 719, and in the first decade of this millennium, we recovered 1241 (Díaz Barriga, 2013).

\subsection{Production Analyzed}

We proceeded to an exhaustive search of refereed publications in digital databases appeared in the years 2002-2012 on the subject of curriculum studies and reforms in Mexico. The writings of Mexican scholars were identified either published in the country or by foreign publishers. We take into account books and book chapters of recognized scientific editorials; research journals; graduate theses or doctoral dissertations; and papers presented by Mexicans in national and international conferences on curriculum studies.

Out of 1241 total documents (books, chapters, articles, theses, papers) published about diverse matters related to curriculum studies, 762 tackled the problem of curriculum innovations; this means that the matter of curriculum innovation covered $61.4 \%$ of the production in the first decade of the 21st century. The authors of this article took on the task of analyzing 762 papers on curriculum innovation to identify a number of trends in them. In the next section we present a quantitative analysis of the curricular production on the subject of curriculum innovation in the preceding decade and then review some trends in Mexico. We analyze the type of production, type of research, topical and educational level at which the papers selected are focused on curricular innovation.

\section{Results}

\subsection{Quantitative Analysis of Curriculum Production}

We must emphasize that the database about curriculum innovation and the information we shall deal with are made up of works published by Mexican authors or authors who reside in Mexico, although the documents (books, articles, papers, theses, chapters) can be published either in foreign or national journals, this means that we are talking about the Mexican production about this subject.

As regards the production type that have been generated about innovations, Figure 1 shows that many papers have been presented in conferences and congresses (392), many of them exhibiting how innovations actually work when put into practice in the classroom; the chart also highlights the quantitative importance of books and articles published by Mexican authors in national and foreign reviews (174), and in our opinion it is very significant that, if we take into account the 73 books and 74 book chapters about this matter, we reach an average of 7 works a year. With regard to the amount of thesis or dissertations that have been gathered, we are sure that the production was actually more important than what we could record, since not all the higher education institutions have digitized versions of those theses and therefore we could not access those materials, but even taking into account these limitations, 41 postgraduate theses is a significant amount, since the result expressed an average of 4 theses a year about curriculum innovations. The institutional documents we could gather were 8 , a number we consider important to account for the curriculum reforms or the educational models regarding the guidelines that are pointed out about innovations.

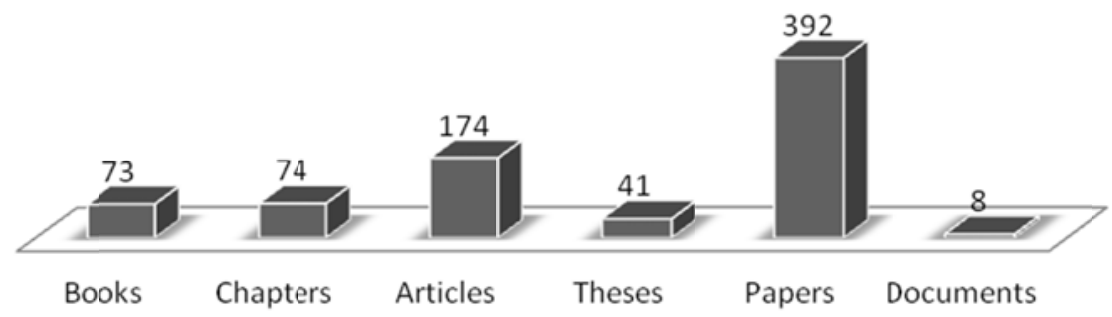

Figure 1. Production Types: Curriculum Innovations 2002-2012

With respect to the kind of research or study that has been reported in the documents that have been classified as innovation matters, we observed the following numbers: 206 empiric, quantitative or qualitative research reports, which means $27.03 \%$ of the production about curriculum innovation; this points out a difference with the previous decade, in which most of the studies about curriculum development consisted in proposals and models. We also found 204 articles about theory, critical analysis or literature review, which in percentage remains more or less the same as in the nineties, $26.77 \%$. $20.47 \%$ of the studies that were published are intervention experiment reports (156), whereas the subject of curriculum innovation models and proposals (122) reaches $26.40 \%$. The works in which authors are proposing reflections about curriculum innovation were 74 (9.71\%). In Figure 2 we present this information. 


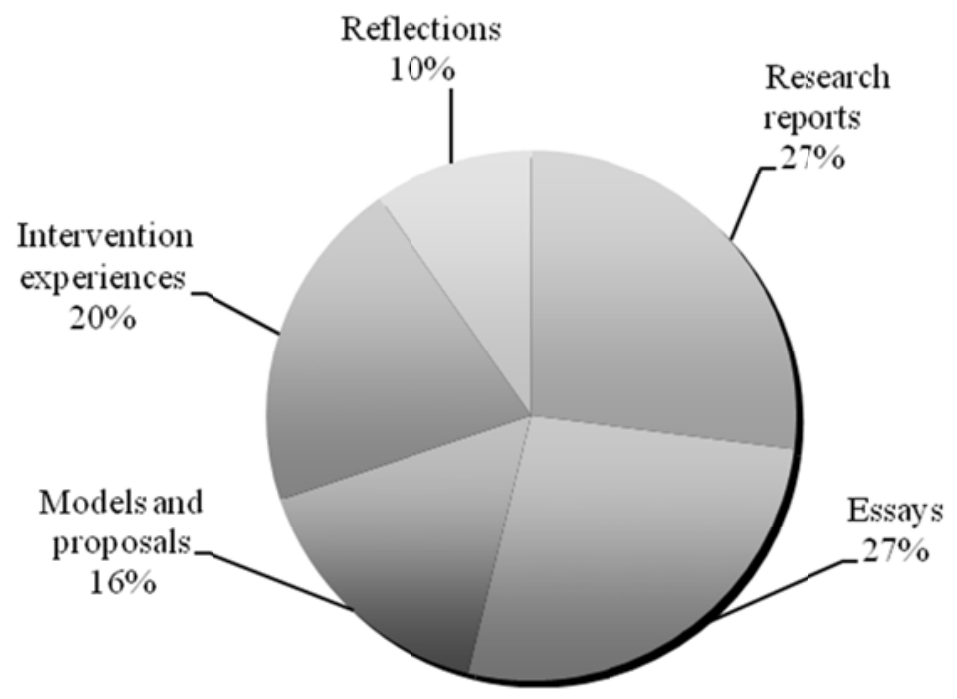

Figure 2. Research types: Curriculum Innovations 2002-2012

If we take into account the study level the documents about curriculum innovation deal with or to which they are addressed, we keep finding the same tendency we could observe in the states of affairs of the eighties and nineties, i. $e$. that most of the production deals with higher education, either professional or university education (460 documents, which means $60.40 \%$ of all the works on this subject). About early education we only found one work $(0.1 \%)$, and for adult education 4 (0.5\%). 7 documents dealt with pre-school (0.9\%), 24 with primary (3.1\%) and 21 with secondary education (2.8\%), which gives for basic education a total amount of 52 documents, $6.8 \%$ of the production about curriculum innovations.. 65 works tackled high school matters (8.5\%) and 25 postgraduate (3.3\%). With respect to the studies that take innovations in a general way or deal with diverse educational levels, we could find 153 of them (20.3\%). Figure 3 illustrates this information.

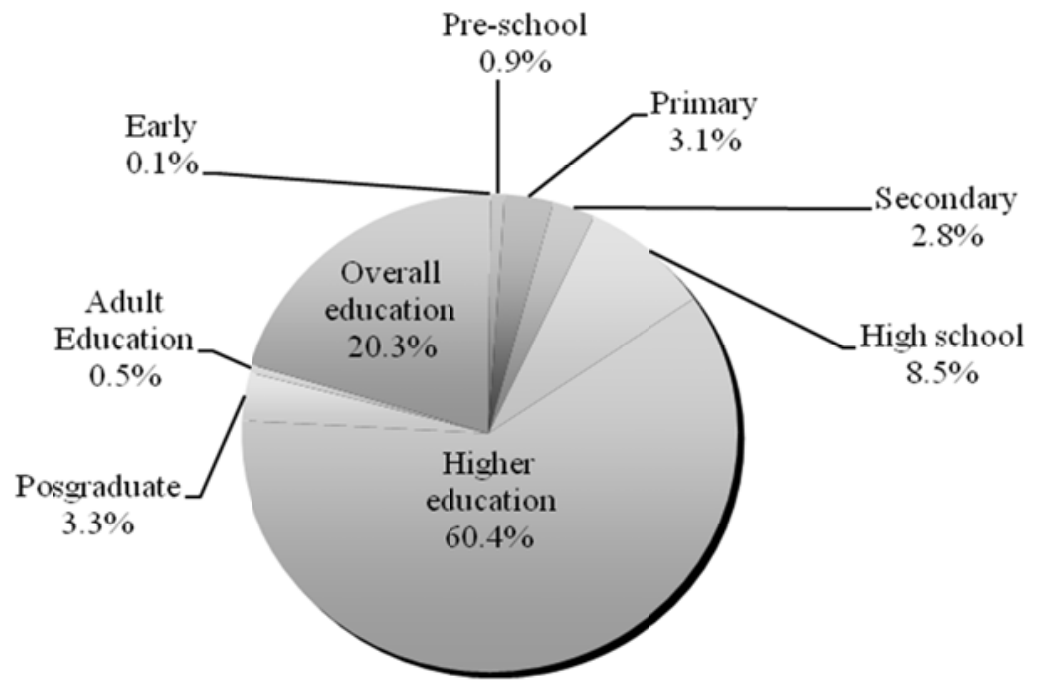

Figure 3. Educational Levels: Curriculum Innovations

We also delimited a whole of subtopics in curriculum innovations and propose the following classification with the respective results (number of documents/percentage). Note that a quarter of the studies tackled the subject of compentences (see Figure 4):

- Incorporation of the competency-based approach (193/25\%).

- Use of the new Information and Communication Technologies (ICT) (122/16\%). 
- Curriculum flexibility (51/7\%).

- Cross-disciplinary topics (education to values, citizenship, environment) (50/6\%).

- Approaches that focus on the student's learning (tutorships, problem-based learning, projects, case studies, linking, on-site training activities, etc.) (122/16\%).

- Professional training and curriculum structure (112/15\%).

- Proposal or analysis of curriculum innovation educational models (77/10\%).

- Curriculum innovation and teachers' training/practice (35/5\%).

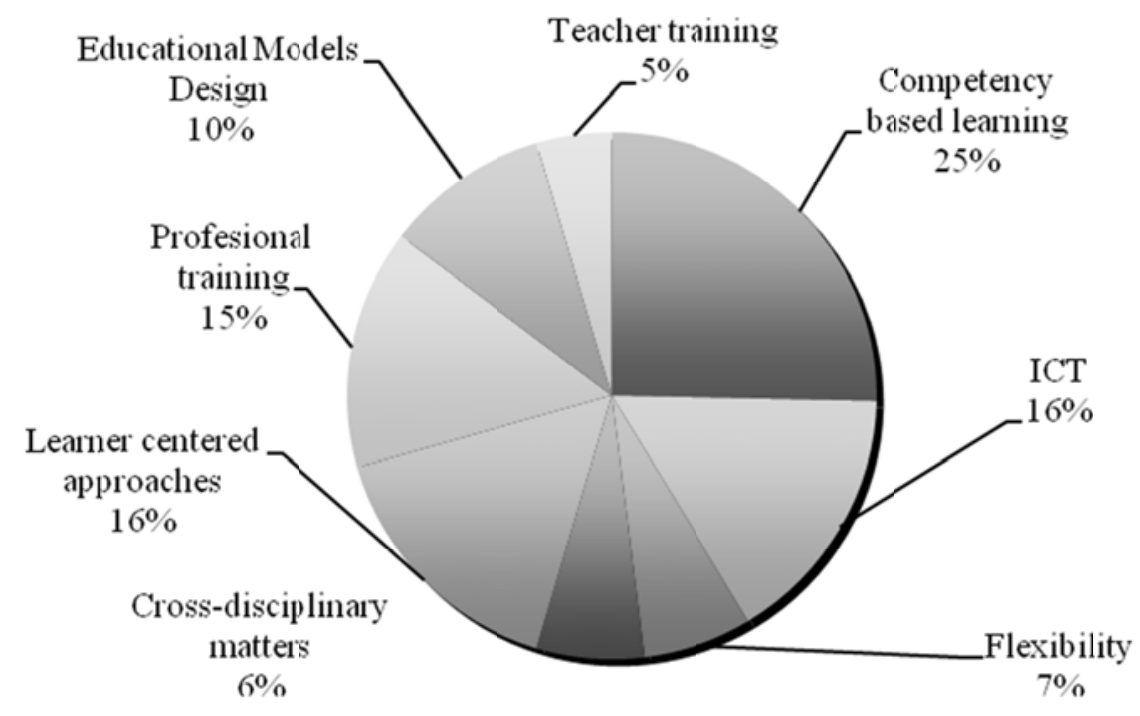

Figure 4. Subtopics: Curriculum Innovations 2002-2012

\subsection{Qualitative Analysis: The Dynamic of Mexican Curriculum Innovation}

As we said yet, the aspect that most contributed to clarify and improve the understanding to the analysis of the production about curriculum in the last decade (2002-2012) was the identification of what we called innovating curriculum models (modelos curriculares innovadores). It is important here to highlight that with the implementation of the far-reaching curriculum reforms in the whole educational system, since the nineties the term innovation used to be associated to the design and implementation of new curriculum models and the operationalization of new methodological prototypes and strategies for teaching and assessment. From the perspective of the education authorities, but also of many authors, this alleged innovation had as purpose to meet the demands that Mexican education would face before a complex and increasingly globalized society, the so-called knowledge society. They also thought that the incorporation of certain innovating models proceeded not only from the apparent need for change in local educational institutions, but that it had been preceded by international trends in educational reform matters and had been promoted by policies that have arisen from national and international organizations not only belonging to the educational sector, but also to the economic and business environment, policies that depended openly on proposals directed to quality assessment, certification and accreditation or assessment related to the financing of education.

We therefore observed that the main support of the educational reforms is the hegemonic discourse about the society's entry to the information society and to globalization. It is also necessary to take into account that there are significant categories in order to understand this evolution, such as the categories of García-Garduño (2011) presented previously. As already stated, the author talks about acculturation and satellization processes of the curriculum field, and this because at some time Mexico undergoes some subordination and assimilation to the way of thinking and ideology about education of other countries. There are also hybridization processes, since structures and practices that stem from diverse origins can combine in order to create new entities. At the same time, this author introduces the category of cosmopolitanism that refers to the defense of emerging spaces, of new cultural and social configurations and, within the field of curriculum, can be related to the multicultural perspectives, the openness to diversity and the balance between local and universal values. Consistent with these notions, we find the existence of tensions, contradictions and exclusions between the discourse of curriculum reform from the point of view of 
international organizations and national authorities, as opposed to the ideas and realities of many educational communities.

Alicia de Alba (2007) asserts that if we analyze the national and regional development indices, the results of those curricular reforms are very poor, and even negative. The point is in her opinion the lack of social project within those reforms and the idea that "innovation", independently of the project to which it is linked, necessarily implies an improvement of the society and education. She questions the hegemonic discourse of the so-called knowledge society and, in any case, suggests that what we need is to reach the plural notion "knowledge societies" "sociedades de conocimientos"), adjectivized with "critical innovation" and "alternative globalization". This kind of innovation only will be possible if we address the existing tensions that stem from the local, singular contexts, in the way of thinking and making curriculum.

Some of the research works we analize deal with the dynamics of the curriculum change processes and the role played by the actors in those changes (Andrade, 2011; Cisneros \& Robles, 2011; Plazola \& Rautenberg, 2009). In all those works the authors report complex processes, never completely free of contradictions and significant strains, where the social and institutional position of the actors and the institutional conditions make possible to explain how people accept or reject the curriculum changes and the innovating proposals. They even report a curriculum change process in higher education within the country's most important university that, although it was seemingly advanced, was completely thwarted because of the polarization between the working teams and the pressure from the authorities that the thing "should remain how they were" ("mantener las cosas como estaban", Silva, 2007, p. 17).

Plazola and Rautenberg (2009) start from the assumption that was already accepted a few decades ago: the curriculum change is more than a technical assembly, because as a social project it must be conceptualized and analyzed from the point of view of the institutional micro-politics. The change in curriculum structures constitutes a perturbing intervention action, since it mobilizes imaginations, spaces of power, ways of participating and positions within the institution. This authors identify at least four stances: the teachers who are part of the "expert" group and who incarnate the proactive group for change; the collectivity who does not take part in the implementation of change, but does not either resist to it; the group who expresses its resistance and articulates to prevent curriculum change; and finally the collectivity of people who show a certain disposition to curriculum reform but only admit it from their own project and interests.

However, in our country we also find a diversity of successful experiences where it has been possible to promote educational change. It has to do with proactive organization experiences that start from needs and actions which emanated from academic communities or teaching or research groups who assumed a leading role and achieved to consolidate successful curriculum projects, whose success has to do with its association to the needs of its context. An illustrative document is the book compiled by Lira and Sandoval (2012), in which they present seven cases as examples of good practices about contextualized training. As regards to higher education experiences, one of them proposes integrated professional competences and puts the emphasis on explaining what are the appropriate teaching and learning methodologies for a competence-based approach from the selected point of view: problem-based learning, project methodology, study case, evidence-based learning, while at the same time considering the importance of the tutorial job in those approaches. They also describe the university training intervention that has been carried out successfully by a Jesuit institution at Guadalajara with two little companies, as a linkage strategy with the productive sector based on the project methodology and the analysis of learning situations. Finally they include the program and methodology of two affective competence-based educational experiences, one of them with teachers who are attending postgraduate studies and the second one centered on the rediscovery of emotion within the classroom, in a technical high school.

All those examples have as overall study framework the analysis of the respective educational reforms and start from the differentiation between the normative prescription and the innovation, that is why it is really necessary to study empirically the teachers' real meaning and performance by means of the inquiry about their actual teaching practices. In general, in examples of good practice in different contexts -many with marginal populations or rural groups- the key factor is to go beyond the hegemonic discourse of the knowledge society and its imperatives. It is more fruitful, while recognizing the existence of global trends, the power to influence from a situated or local viewpoint that addresses the diversity and needs of specific contexts.

\subsection{Innovating Models: Competences and Curriculum Flexibility}

As regards the diversity of identified innovating models during the nineties (competence-based curriculum, curriculum flexibility, learner-based curriculum, cross-disciplinary curriculum, amongst others) we do not observe unifying visions or conceptions related to those alleged curriculum innovations. Even if the studies that analyzed 
thoroughly the concept of innovation itself or reported the curriculum reality in its transfer to the educational institutions, we found that the innovation itself was understood in many different ways. Countless times the curriculum innovation was considered as synonymous with the incorporation of the current educational novelties, without an in-depth reflection about its implications or a clear schedule for its incorporation to the curriculum structures or to the classroom reality, and rather overlooking the educational culture and practices that prevail in a given educational community.

Pursuing the logic of a centered and "upside down" and "outside in" designed curriculum, that has been the overall accepted approach in our educational system since the seventies, many of the innovations kept emerging with a vertical implementation approach, with the authorities or experts imposing to the actors (teachers and students). Only in a few cases innovation was understood as the need for a profound change in social and educational paradigms and practices in an educational community, as a product of the reflection and appropriation of the people involved in that process (Díaz-Barriga \& Lugo, 2003; Díaz-Barriga \& Barrón, 2012).

For their part, the sociologists who have studied about the matter of curriculum reform and educational change assert that probably the main problem of public education is not the resistance to change itself, but the "presence of many innovations that have been dictated or uncritically and superficially adopted on a fragmented basis" ("la presencia de muchas innovaciones mandadas o adoptadas acrítica y superficialmente sobre una base fragmentada”, Fullan \& Hargreaves, 1999, p. 23). Because of the lack of a systemic vision and a social project, in many educational reforms there is an obvious risk that the prevailing approach will be utilitarian and technocratic, completely lacking in ethical commitment, which leads to the standardization and diminishment of the professionalization of educational task, to the loss of the educational priorities and to an uncritical adoption of imported fads. Particularly the referred curriculum studies agree that the educational change has to be systemic and not remain on the superficial formal layers. They also agree that the problem of implementing those innovations within the classroom cannot be reduced to the teachers' union conditions or to how their professional exercise affects the process, although both are undoubtedly essential factors.

Since the "innovation historically has been connected with research for the technological development, made conditional to a great extent on the development of economy" ("la innovación en la historia se reconoce vinculada a la investigación para el desarrollo tecnológico, condicionada en gran medida al desarrollo de la economía”, Martínez, Toledo \& Román, 2009, p. 2), the discourse of innovation stems from the pressure to translate the principles of the new market economy into training strategies, particularly in higher education. In this case, our universities do not fit the model of "innovating entrepreneurial university", but, according to those authors, they have been orienting disproportionately towards the technical and instrumental abilities, to the detriment of a general and solid training. And it is precisely in this direction that the matter of competences in higher education has been understood: the technical and instrumental qualification and training in detriment of a more holistic and sociocultural attitude towards the matter of competences.

The definitions that have been generated during the last decade, and from different points of view, about the concept of competency are very diverse. The term "competence", that emerges in the world of labor was adopted relatively quickly in the field of education, especially with regard to the curriculum design, the training of professionals, the educational assessment and the teaching and learning process. Theoretically and with respect to the redaction of the documents on which the curriculum reforms are based, the most widespread definition of the term competence in our country can be found in authors such as Perrenoud (2004), for whom competence is the possibility to mobilize and integrate different knowledge and cognitive resources when facing an unprecedented situation or problem, since the individual then has to show his/her capacity to resolve complex and open problems in different stages and moments. Nevertheless in practice, when implementing this definition within the classroom what we find are reductionist visions that limit the notion of competence to a "know how to carry out" some proceeding understood as a preconceived plan or routine that consists in following instructions. In many study plans of higher and basic education, the competency derivation consists in a list of tasks or discrete and fragmented actions that result forms the functional analysis of a performance. This last vision, that stems forms the training of professional technicians and of semi-qualified manpower, does not work that well when transferring to professional, higher or even basic education. In diverse studies that have been carried out during the nineties the author highlighted that there is a real confusion and misunderstanding within the school communities not only about the term competence, but also about its implementation in the classroom; this is why it has been possible to conclude that this kind of innovation has generated more strains and resistance than any other amongst teachers and students, and this is why some authors can assert that it conceals “a disguise of change” (“un disfraz de cambio”, A. Díaz-Barriga, 2006). 
In our opinion, what hasn't been understood yet is that in order to teach and learn by competences it is necessary to create didactic situations that allow to place students (or teachers in training/in service) face to face with the tasks they are expected to carry out. It is also necessary for them to achieve and to learn to mobilize the resources they need and to do so based on metacognitive reflection or self-regulation processes. The training programs and objectives, when considered from the point of view of competence-based education, do not lead to terms of static or expository knowledge, but in terms of generative activities and problem-task that the individual in training will have to face. However many programs that are said to be based on competences actually are lists of subjects with disciplinary content, proceedings and attitudes outlines that should supposedly be taught, without raising again the didactic framework and without approaching reality and the problems faced by the university professionals.

One of the aspects that uses to be invoked to characterize the matter of innovation has to do with flexibility as a key term to progress in the curriculum innovation processes, covering times, spaces, tasks, work relations, etc. to learn new professional abilities. Therefore the educational institutions will have to adapt to the needs of the society and to foresee them, and "particularly in developing countries it is urgent to establish new university models more appropriate to the needs and more likely to favor disciplinary and geographical synergies" ("sobre todo en los países en desarrollo es urgente establecer nuevos modelos universitarios más adaptados a las necesidades y susceptibles de propiciar sinergias disciplinarias y geográficas”, Medina, 2008, p. 41). For this author, one of the main implications of what we mentioned about the subject of curriculum design is that it is necessary to try a new definition of the traditional curriculum and to redraw the places where learning takes place in order to create "learning environments that are flexible, stimulating and motivating, and able to exceed the limits of standardized curricula, with division by subject, limitation in time and strict pedagogies" (“ambientes de aprendizaje que sean flexibles, estimulantes y motivadores, y que superen las limitaciones de currículos estandarizados, división por materias, limitados tiempos y rígidas pedagogías”, Medina, op. cit., p. 44). From a narrow point of view this trend only favors the learning that prepare the individuals to perform in the new entrepreneurial organizations, but from a wider perspective of professional training it should allow for the contact with the social reality, impacting on society as a whole. Martinez (2011) says with regard to the latter that curriculum in higher education must be transformed taking into account the following aspects:

- Flexible and mixed curriculum organizations, between courses/modules and projects.

- Development of diverse competence types.

- Professional practices and stays as part of the curriculum, associated with the reality and the achievement of abilities.

- New ways to assign credits to diverse contents and activities, and new strategies for the recognition and transfer of credits.

- A social service as part of the curriculum.

- Development of an in-service or in situ training.

- Working groups with as purpose to approach processes or problems.

It is obvious that the above-mentioned points necessarily entail a new conception about curriculum structure, with substantial changes in the logic by which the curriculum maps are organized and shaped. Nevertheless we find here a significant strain: if we analyze what they now call in Spanish the "curriculum meshes" ("mallas curriculares") resulting from the last curriculum reform, it is clear that the curriculum structure and organization in practically all levels of the Mexican educational system is still strongly disciplinary, whether it is organized by subjects or by knowledge areas. And although during the last decades the experts have been reporting a tendency for competence-based curriculum, or at least the encouragement of cognitive abilities and specific skills to proliferate, what actually occurs is that the prevailing logic that underlies the curriculum design is still the positivist vision that leads to a non-cross-disciplinary segmentation of the courses, not to an inter- or cross-disciplinary conception of the units or cores of those curriculum meshes. In some cases we observe a kind of hybrid consisting in the traditional disciplinary curriculum structure with the inclusion of courses drawn up according to the cross-content or cross-disciplinary approach or the learner-centered approach. This is why we can assert that rethinking the knowledge epistemology that underlies the curriculum logic is still an open question and that, in this regard, “innovation” hasn’t yet fulfilled its duty (Díaz-Barriga, 2010; Díaz-Barriga \& Barrón, 2012).

Some of the studies produced during this decade addressed the analysis of the teachers' new role as a host teacher in enterprise, a trend that has become increasingly pronounced in academic and entrepreneurial communities and about which there are already experiences that can be reported (Martínez, 2006; Pedroza, 2004; Díaz-Villa, 2005). 
Although the need for cooperation between business and university is not new, it is necessary to keep holding a thorough discussion about the intentions and purposes of the current and future university in order to present proposals and alternatives able to define a fair cooperation without any kind of subordination of either parts. Part of the dilemma can be resumed as the need to articulate entities with different times, rhythms and organizational structures and with their own conception of autonomy so that this articulation offers for both parts benefits, or to move forward towards a kind of relationship that can instill the universality of the entrepreneurial culture to the sometimes to locally oriented traditional scientific communities and to the humanistic culture (Barrón \& Gómez, 1999; Barrón, 2011).

\section{Conclusions}

Curriculum reforms in Mexico during the last decade has been marked by the hegemonic discourse of the entrance to the knowledge society and by the incorporation of the managerial neoliberal models which point out elements such as the quality guarantee, the competency-based curriculum design, the accountability and the regulation of the educational system by means of standardized assessments that are condition to the educational funding. From this point of view it seems that the educational policies about curriculum are deriving to some interest to homogenize or to seek equivalence for the school curriculum, in order to make of it some kind of "international curriculum" by means of redefining the competency standards. This represents a major problem if we take into account the great cultural diversity of our country, and also the obvious socioeconomic inequality. But at the same time, and in a contradictory way, the curriculum reforms claim for innovation, for the search of a pedagogical renewal that pretends to recover proposals that emerged in the movement of the active school and of the progressive and experiential education. Similar contradictions can be found in the sphere of the assessment of learning with regard to the school curriculum, since whereas curriculum prescribes authentic assessment within the classrooms, the standardized far-reaching tests (PISA, Enlace) have the most important weight before the institutions and the public opinion.

What we can identify in this state of affairs is a lack in theoretical and conceptual understanding and of appropriation of the innovations by the teachers, who have not been able to get fully involved in collegial training processes or in the development of the curriculum programs they teach. Usually the teachers consider that no appropriate infrastructure is available, neither the needed condition to ensure the transformation process of teaching within the classroom; on of those factors of resistance has been the diversification of roles and academic responsibilities, that disrupt not only their working conditions, but also their professional identity.

The possibilities to make curriculum more flexible and the academic actions that result from it also mean new regulation mechanisms for educational practice, and those lead to analyze and reformulate the university rules, mainly with regard to the monitoring and authorization of actions that stem from the study plans. We can highlight the need to rely on a tutorship program that has been specifically developed for the features of the flexible curriculum structure. This proposal has to come from the institutions itself, and not remain within the boundaries of isolated training courses and workshops for teachers.

In addition to this it is important to mention how difficult it can be to implement any flexibility strategy related to the decision-making processes, since we still lack a real democratic tradition; besides, the academic administrative structures are ruled more by tradition and customs than by the needs for change, in a logic of institutional rationality. As shown throughout this paper, the flexible curriculum organization requires a kind of curriculum an institutional management based on different paradigms, able to deal with a wide range of phenomena, from the new knowledge production forms, based on multidiscipline and interdiscipline to the creation of hybrid degrees and a credit system with opportunities for inter- and intracurriculum and institutional mobility. That is why the matter of curriculum flexibility is not a merely technical issue.

As regards to the competence model, either with respect to the teachers' or the students training in higher education, we usually observe a reductionist look and a lack of understanding and appropriation within the classrooms of the so-called competency-based education, since we don't find yet a real approach in which the students are actually facing relevant situations for the society and their future profession and where they are supplied with abilities to build and rebuild knowledge, to make decisions or to generate solutions.

The curriculum reforms bring about certain technologies for the actors' regulation, and amongst them the most important is the function of the curriculum base documents; i. e. the teachers become the readers of those texts, since they act as receptors of the experts' knowledge (Ziegler, 2003). In that way, the base documents of the curriculum reforms are intended to serve as normalization tools for the teaching practices, but they actually do not achieve to 
have an impact, at least not as expected, in everyday school interaction. That is why a series of educational proposals or models, undoubtedly harmonized with the most promising progresses and trends in subjects related to curriculum and didactics, do not succeed in becoming actual innovations within the classroom, since they do not influence the actors' practices, either because they do not meet their needs and demands or because they do not understand them comprehensively and their cognitive cost is too high for them.

Finally, according to Pinar (2014) certain concepts "reverberates" through the state of affairs in curriculum studies in many countries: globalization, technology, standardized assessment, competencies, and generates specific structures in each country. We need to emphashize historical, cultural and social context to understand nationally and locally aspects at the same time as globalization trends.

\section{References}

Andrade, R. A. (2011). El currículum de bachillerato general por comptencias (BGC) de la Universidad de Guadalajara. In S.C. Hernández, \& R.A. Andrade (Comps.). Aprendizaje y competencias en educación. Visiones y reflexiones (pp. 15-57). Guadalajara, México: Universidad de Guadalajara.

Barrón, C. (2011). Professional education in Mexico at the beginning of the twenty-first century. In W. Pinar (Ed.). Curriculum studies in Mexico. Intellectual histories, present circumstances (pp.181-206). New York: Palgrave McMillan. http://dx.doi.org/10.1057/9780230337886.0013

Barrón, C., \& Gómez, J. (1999). La flexibilité du curriculum, seule alternative pour la formation professionnelle universitaire? Paper read at the AFIRSE Conference "La educación desde la perspectiva de la globalización-mundialización”. Paris: AFIRSE.

Cisneros, L., \& Robles, S. (2011). El profesor de bachillerato y su visión acerca de las competencias para la acción tutorial. In S. Hernández, \& R. Andrade (Comps.). Aprendizaje y competencias en educación. Visiones y reflexiones (pp. 187-220). Jalisco, México: Universidad de Guadalajara.

Creswell, J. W., \& Plano-Clark, V.L. (2010). Designing and conducting mixed methods research. Thousand Oaks, California: Sage.

De Alba, A. (2007). Currículum-sociedad. El peso de la incertidumbre, la fuerza de la imaginación. México: Plaza y Valdés.

Díaz Barriga, A. (2006). El enfoque de las competencias en la educación ¿ Una alternativa o un disfraz de cambio? Perfiles Educativos, 38(111), 7-36.

Díaz Barriga, A. (Coord.) (2013). La investigación curricular en México. La primera década del siglo XXI (2002-2012). México: Consejo Mexicano de Investigación Educativa (COMIE).

Díaz Barriga, A., Barrón, C., Carlos, J., Díaz Barriga. F., Torres, R., Spitzer, T., \& Ysunza, M. (1995). La investigación en el campo del currículo. Procesos curriculares, institucionales y organizacionales. México: Consejo Mexicano de Investigación Educativa.

Díaz Barriga, F. (2010). Los profesores ante las innovaciones curriculares. Revista Iberoamericana de Educación Superior, 1(1), 37-57.

Díaz Barriga, F. (2014). Curriculum research in Mexico. In W.F. Pinar (Ed.). International Handbook of Curriculum Research. Second Edition (pp. 329-350). New York: Routledge.

Díaz Barriga, F., \& Barrón, C. (2012). Educational innovation and curriculum reform in Mexico. Transnational $\begin{array}{lllll}\text { Curriculum } & \text { Inquiry, } & 9(2), & \text { 67-81. } & \text { Retrieved }\end{array}$ http://ojs.library.ubc.ca/index.php/tci/article/view/183765/183737

Díaz Barriga, F., \& Lugo, E. (2003). Desarrollo del currículo. In A. Díaz Barriga (Coord.). La investigación curricular en México. La década de los noventa. Collection: La Investigación Educativa en México 1992-2002, vol. 5, cap. 2, pp. 63-123. México: Consejo Mexicano de Investigación Educativa (COMIE).

Díaz-Villa, M. (2005). Flexibilidad y organización de la educación superior. In R. Pedroza, \& B. García (Comps.). Flexibilidad académica y curricular en las Instituciones de Educación Superior (pp. 63-117). México: Porrúa.

Fullan, M., \& Hargreaves, A. (1999). La escuela que queremos. Buenos Aires: Amorrortu.

García-Garduño, J. M. (2011). Acculturation, hybridity, cosmopolitanism in Ibero-American curriculum studies. In W. Pinar (Ed.). Curriculum studies in Mexico. Intellectual histories, present circumstances (pp. 137-163). New York: Palgrave McMillan. http://dx.doi.org/10.1057/9780230337886.0011 
Lira L., \& Sandoval, S. L. (Coords.). (2012). La formación en contexto. Reflexiones y prácticas exitosas. Guadalajara, México: Instituto Superior de Investigación y Docencia para el Magisterio, Gobierno del Estado de Jalisco.

Mardones, J., \& Ursúa, N. (2003). Filosofía de las ciencias humanas y sociales. México: Fontamara.

Martínez, L. (2006). Flexibilización curricular. El caso de la UABC. México: Plaza y Valdez.

Martínez, L. (2011). El currículo y la innovación. In Formación para la innovación. El currículo ante las demandas de la nueva economía (pp.75-127). México: ANUIES/UABC.

Martínez, L., Toledo, D., \& Román, R.D. (2009, September). El currículo frente al pensamiento de la innovación. Un estudio en algunas carreras de ingeniería. Paper presented at the X Congreso Nacional de Investigación Educativa, COMIE, Veracruz, México.

Medina, L. (2008). Innovación curricular y formación docente: La visión de la ANUIES. In E. Lugo (Comp.). Reformas Universitarias: su impacto en la innovación curricular y la práctica docente (pp. 39-52). México: UAEM/ANUIES.

Pedroza, R. (2004). Propuesta de un modelo curricular flexible para mejorar la calidad de la formación profesional. DEP Cuadernos para la educación superior. México: Universidad Autónoma del Estado de México. Retrieved from http://cuib.unam.mx/ escalona/pagina/LECTURA1.pdf

Perrenoud, Ph. (2004). Diez nuevas competencias para enseñar. Barcelona: Graó.

Pinar, W. F. (2014). Introduction. In W.F. Pinar (Ed.). International Handbook of Curriculum Research (pp.1-14). Second Edition. New York: Rouletdge.

Plazola, M. R., \& Rautenberg, E. (Coords.). Sujetos y procesos del cambio curricular. México: Universidad Pedagógica Nacional.

Silva, A. (2007). La enseñanza, el ejercicio y la investigación en Psicología en un mundo tolerante y plural. México: Editorial PAX.

Ziegler, S. (2003). Los docentes como lectores de documentos curriculares. Aportes para el análisis de la recepción de la reforma curricular de los años noventa en Argentina. Revista Mexicana de Investigación Educativa, 8, 653-677. 